\title{
Receptivity to the Production of Product Service Systems in the UK Construction and Manufacturing Sectors: A Comparative Analysis
}

\author{
M. Cook ${ }^{a *}$, A. Gottberg ${ }^{b}$, A. Angus ${ }^{b}$, P. Longhurst ${ }^{b}$. \\ a Department of Design, Development, Environment and Materials, Open \\ University, Walton Hall, Milton Keynes, Buckinghamshire, UK, MK7 6AA \\ ${ }^{\mathrm{b}}$ Department of Environmental Science and Technology, School of Applied \\ Sciences, Cranfield University, Cranfield, Bedfordshire, UK, MK43 OAL
}

\begin{abstract}
Trajectories of service innovations emanating from manufacturing sectors have been of particular interest to those wishing to improve resource productivity and promote sustainable development. Research has focused on product service systems (PSS), which are a category of service innovations deliberately designed to offer superior environmental performance. This paper draws on research which explored whether trajectories of PSS can be induced on new UK housing developments to satisfy household demand and prevent household waste. The research was undertaken with a UK speculative house-builder and facilities management service providers from its supplier network. Qualitative data were collected via interviews and focus groups to enable rich accounts of the range of factors in these firms' selection environments which affect receptivity to PSS production to be developed. These were compared with factors affecting receptivity to PSS production identified in a study of UK manufacturers. The results show that in contrast to the manufacturing study, clear drivers for PSS delivery on new housing developments are absent in external selection environments of participating firms and uncertainty associated with the potential of PSS concepts to satisfy household demand inhibits development of requisite competence for PSS delivery within these. Thus further research is needed to explore new PSS supply arrangements involving a range of household service providers.
\end{abstract}

Key words: waste prevention; sustainable urban environments; product service systems.

* Corresponding author

Tel. (01908) 655964

E-mail address: matthew.cook@open.ac.uk (M. Cook). 


\section{Introduction}

While a range of promising new technologies have been developed which may enable significant improvements in resource productivity to be attained, adoption rates associated with these have been disappointingly low (Elzen et al., 2004). The obduracy of existing technological systems which embody not just technologies but also ways of thinking about these are of particular concern. System level phenomena such as 'lock in' of incumbent technologies and consequent 'lock out' of new, perhaps more environmentally benign technologies are problematic. However, those drawing on the evolutionary tradition of technological change argue that the emergence of new technological trajectories may lead to the opening of pathways toward sustainable development. The emergence of performance orientated service innovations have been of particular interest in this regard (Weizsacker et al., 1997; Hawken et al., 1999; Stahel, 2006; Mont and Emtairah, 2008).

A number of performance orientated service innovations have been found in manufacturing sectors (Baines et al., 2007). Research shows that some manufacturing firms have used the goods they produce as platforms for such service innovations in intermediate and final markets (Howells, 2002). These include complements to goods such as extended warrantees and lease agreements, while in other instances, service innovations are supported by goods produced but are potential substitutes for these. Examples include, document handling services provided by manufacturers of photocopiers and power services provided by manufacturers of gas turbines (Stahel, 2006). Manufacturers and their customers have been found to express a preference for service innovations as in contrast to traditional approaches based on the production and consumption of goods, performance is defined and rewarded in terms of results achieved (Bartolomeo et al., 2003). Indeed, performance orientated service innovations aim to maximise the performance of goods, labour and infrastructure which form the basis of such offerings (Williams, 2007).

Similar performance orientated service innovations have been found in among others, utility sectors (Manzini and Vezzoli, 2003). Energy service companies (ESCOs) provide services which aim to add value to primary energy inputs by meeting additional customer requirements (Steinberger et al., 2009). Services may be provided to ensure a given level of comfort, certain lighting levels, room temperatures or guarantee supplies of hot water and/ or electricity at a reduced cost (Sorrel, 2007). Similar service innovations have also been found on household markets (Beherendt et al., 2003). For example, a range of service innovations have been identified and reviewed including, house cleaning services, repair services, home delivery services (ecological food and groceries), energy services, recycling and repair services and washing services (Halme et al., 2004; Halme et al., 2006; Halme et al., 2008). In general household demand for services is thought to be income elastic, i.e. demand for services increases as incomes rise. A trend has emerged in western economies for households to consume services at the margin (Bryson et al., 2003).

Various product focused definitions have been developed from case study research to account for the range of service innovations which have been found in intermediate and final markets and include: eco-efficient producer services (Zaring et al., 2001; Bartolomeo et al., 2003), eco-efficient services (Hockerts, 1999; Meijkamp, 2000; Brezet et al., 2001), eco-services (Beherendt et al., 2003) and product service systems (Goedkoop, 1999; Mont, 2004; Tischner et al, 2002; Morreli, 2006; Manzini and Vezzoli, 2003). Discursive closure has not been achieved, rather these definitions are contested. However, the latter term product service system (PSS) is used extensively in recent literature. A number of definitions of PSS can be identified including: 
A product service system is defined as a marketable set of products and services capable of jointly fulfilling people's needs (Goedkoop et al., 1999)

A product service system consists of tangible products and intangible services designed and combined so that they are capable of fulfilling specific customer needs (Tischner et al., 2002)

A system of products, services, networks or actors and supporting infrastructure that is developed to be competitive, satisfy customers and be more environmentally sound than traditional business models (Mont, 2004).

Case study research has also enabled PSS types to be elaborated, which in theory at least, may achieve significant improvements in resource productivity (e.g. material and energy) and help mitigate the environmental, social and economic impacts associated with resource extraction, synthesis, use and disposal. A common categorisation of PSS types include (Hockerts, 1999; Roy, 2000; Cook et al., 2006):

Product Orientated PSS: Within this type of PSS, ownership rights of the material artefact (good) are transferred to the customer and a service is provided to ensure the good performs as intended over a given period of time. Examples include warranties and maintenance contracts.

Use orientated PSS: Within this type of PSS, the ownership right of the material artefact (good) are retained by the service provider (who may or may not have manufactured it) and the customer purchases use of the material artefact over a given period of time. Examples include, leasing, renting and sharing/ pooling.

Result orientated PSS: While these are similar to use orientated PSS, ownership rights of the material artefact (good) required for service delivery are retained by the service provider (who may or may not have manufactured it); in contrast to use orientated PSS the customer purchases an outcome/ result of service provision, which is often specified in terms of performance not the use of a good over a period of time. For example, instead of renting a washing machine, households use a laundry service to clean clothes and linen.

A number of ex post environmental assessments have been completed to identify the impact of these PSS types on the environment (Tukker and Tischner 2006). These are founded on case study research of PSS offerings on intermediate and final markets. For example, Netherlands Government funded research showed that a large laundry service could achieve factor 10 reductions in water consumption and perhaps even factor 16 reductions in detergent use through water and detergent recycling compared with domestic washing. However, the large laundry could only achieve factor 3 improvements in energy consumption because some energy savings are offset by higher wash temperatures, more artificial drying and energy for transport (van der Hoed, 1997).

In general the environmental assessments draw attention to a number of environmental dis-benefits associated with PSS (Tukker and Tischner, 2006). These include possible increases in emissions to air (e.g. greenhouse gas emissions) from transport aspects of PSS delivery and so called rebound effects, i.e. increases in demand induced by PSS which reduce net gains in resource productivity. The environmental assessments also call into question initial estimates of improvements in resource productivity which could be gained from PSS. Instead of factor four improvements, product and use orientated PSS are now thought likely to yield factor two improvements in resource productivity 
(Tukker and Tischner, 2006). In some instances it has been suggested that traditional household consumption using eco-designed goods may provide greater opportunities to improve resource productivity in household markets than product and use orientated PSS (Behrendt et al., 2003). However, the literature remains positive about result orientated PSS. Given their focus on outcomes and results, this PSS type is thought to offer the possibility of 'factor $X^{\prime}$ improvements in resource productivity (Tukker and Tischner, 2006).

Crucially, the environmental assessments also show that services are not inherently more resource efficient than traditional production and consumption based on the production and exchange of goods (Tukker and Tischner, 2006). This adds support to the view that improvements in resource productivity are unlikely to arise automatically from trajectories of service innovations which emerge in response to for example, changes in economic conditions (Mont and Lindhqvist, 2003; Ceschin and Vezzoli, 2010). Thus research is needed to explore how trajectories of service innovations may be purposively managed to improve resource productivity. On the one hand, trajectories of service innovations could be shaped and modulated, to transform service innovations into PSS: cleaner products (services in this instance) which are deliberately designed to improve environmental performance. Interventions might include adoption of voluntary environmental indicators specifically designed to monitor and manage the environmental performance of service innovations, to enable these to be transformed into PSS. On the other hand, trajectories of PSS could be deliberately induced in certain contexts to improve environmental performance. Interventions might include, deliberate transfer of PSS concepts from academia to firms which may be amenable to PSS production, where PSS may enable significant improvements in environmental performance to be gained. Importantly, within both approaches, PSS concepts aim to build on sociotechnical dynamics and are therefore quasi evolutionary. Evolutionary accounts of technical change use the notion of the selection environment to account for the range of factors which serve to favour some innovations over others. In order to shape, modulate and induce PSS in certain contexts, PSS concepts must match the requirements of selection environments associated with these. In certain contexts, selection environments may be receptive to PSS concepts, while in others they may be less so.

The UK has an ambitious housing growth strategy to develop some 2 million new homes by 2016, with a further 3 million planned for 2020 (Williams, 2010) The vast majority of new homes will be provided on new housing developments comprising private dwellings built by speculative house-builders. Such housing developments may provide promising contexts for PSS production. For example, service centres for PSS production might be built on new housing developments and provide opportunities to minimise transport distances in PSS delivery and environmental impacts associated with these; and, the emergence of car sharing schemes and energy services ibid may indicate receptivity to PSS. However, while the role speculative house-builders in providing built form more or less amenable to PSS is recognised (Halme et al., 2008), little is known about speculative house-builders and PSS production. Thus the selection environments of a speculative house-builder and service providers from its facilities management supplier network are explored in this paper, to determine whether these are receptive to PSS production on new housing developments. Both an approach to transferring the PSS concept and its knowledge set from academia to firms and an analytical framework developed to explore receptivity to PSS production in the UK manufacturing sector were used to facilitate analysis (Cook et al., 2006). This enabled comparisons with receptivity to PSS production in the UK manufacturing sector to be drawn out and further insights on PSS production gained. 
This comparative analysis enabled a number of methodological concerns identified in PSS literature to be addressed (cf. Mont and Tukker, 2006; Tukker and Tischner, 2006) including: the need to study PSS production with particular reference to business decisions, decision making processes, organisational structure and supply chain relationships; to link case studies and undertake rigorous cross case analysis; and, to undertake research using the same analytical approach. In general, the paper provides a foundation of knowledge which assists in efforts to develop a comprehensive understanding of factors that affect choices of firms with regard to developing products and services in an environmentally sound manner, with a holistic/ systemic perspective in mind. The paper is structured as follows. Details of the research method are presented in the next section. Factors affecting receptivity to PSS production in the housebuilder and service providers from its facilities management supplier network are presented and compared with the results from the manufacturing study, in the following section. Conclusions are presented in the last section.

\section{$2 \quad$ Research Method}

The research was conducted with a UK based speculative volume house-builder and service providers from its facilities management supplier network. Speculative house-builders are often the main actor in the construction of new UK housing developments. Such firms typically provide a range of after sales products (including curtains, carpeting and a range of household appliances) to households moving onto their new developments. The research focused on receptivity to the production of PSSs which could be included in portfolios of after sales products. In order to explore this, the PSS concept and its knowledge set were transferred from academia to participating firms and an associated analytical framework used to identify factors which affect receptivity to PSS production on new housing developments. Both the approach to technology transfer and associated analytical framework were drawn from an earlier study in which receptivity to PSS production was explored in the UK manufacturing sector (Cook et al., 2006). Details of these are given below.

\subsection{The AMR Approach to Technology Transfer and Associated Analytical Framework}

The Accessibility-Mobility-Receptivity (AMR) approach is based on the view that technology transfer cannot be characterised as simply technology push or technology pull (Trott,1998). Rather, according to the AMR approach, technology transfer is an interactive process involving intermediaries who translate knowledge of the new technology and that associated with the context in which it is to be deployed ibid. Transfer and translation involves intermediaries who interact between academia and industry. Search activities are undertaken by both firms and academia. Thus three sub processes constitute the overarching technology transfer process: accessibility the availability of technology and information about them; mobility the movement of technologies and the channels (e.g. intermediaries) through which they are transferred; receptivity the ability and willingness of the receiving organisation to accept, absorb and utilise a given technology (Seaton and Cordey-Hayes, 1993). Please see Figure 1 below for an illustration of the interactive AMR approach. 
Please insert Fig. 1 hereabouts

This interactive approach was developed to transfer novel technologies such as the PSS concept. It was used in the earlier study to transfer the PSS concept and knowledge from academia to firms from the UK manufacturing sector (Cook et al., 2006). This study shows that successful transfer of PSS concepts is possible when the following is attained ibid:

- Accessibility: the PSS concept and its knowledge set is accessible in conceptual and practical terms

- Mobility: the PSS concept and its knowledge set is moved through intermediary channels, from academia to firms

- Receptivity: potential adopters are both able (in terms of resource and competence) and willing to accept, absorb and utilise the PSS concept and its knowledge set.

An analytical framework was developed to identify factors which affect receptivity to PSS production among manufacturing firms. Within the analytical framework receptivity is defined as:

The extent to which there exists not only a willingness (or disposition) but also an ability (or capability) in different constituencies (individuals, communities organisations, agencies, etc.) to accept, absorb and utilise a technology (Seaton et al., 1998.

The analytical framework draws on evolutionary accounts of technical change which use selection environments to account for the factors which serve to favour some innovations over others (Nelson and Winter, 1982). Receptivity to PSS production arises from the interplay of firm's external and internal selection environments (Cook et al., 2006). Seen this way, while manufacturing firms may produce PSS in response to changes in their external selection environments (e.g. environmental regulations), PSS production must also fit to some extent, the requirements of their internal selection environments, e.g. their corporate competences. Qualitative data were collected to identify and provide rich insights on such attributes of firms selection environments. Data were collected via multiple methods (e.g. interviews) from multiple sources including literatures (e.g. innovation studies) and twenty manufacturers of which four formed the focus of case studies. A template approach to coding and clustering was used to analyse data (Miles and Huberman 1994; Robson 2002). Template codes were determined a priori, from literature and an initial read of primary data. Text segments provided empirical evidence for the template codes. These were reviewed to identify recurring themes: clusters of data which reveal the specific 
attributes of participating firms selection environments which affect receptivity to PSS production, e.g. specific corporate competences necessary for PSS

production. The resultant template comprising codes and clusters formed the basis of an analytical framework (see table 1 below). Since little was known about these phenomenon the research was classified as exploratory and the analytical framework as a heuristic - a guide

Please Insert Table 1 hereabouts 
2.2 Using the AMR approach to transfer the PSS concept and its knowledge set from academia to participating firms from the UK construction Sector

A research team was established comprising one representative from the housebuilder and representatives from two UK universities. Consistent with the AMR approach and following Cook et al. (2006), the transfer of the PSS concept and its knowledge from academia to participating firms involved: making PSS concepts and their knowledge set accessible to participating firms; the research team acting as intermediary to transfer the PSS concept and its knowledge set from academia to participating firms; analysis of receptivity to PSS production on new housing developments among participating firms using the analytical framework. The AMR approach was applied in three phases of research. During each phase activities were undertaken in pursuit of all three requirements for successful PSS transfer detailed above.

\section{Phase 1}

Literature was reviewed to identify and make accessible PSS definitions, types including product, use and result and case examples of actual and/ or potential PSS commercial and environmental performance. A focus group was held in which this knowledge was transferred by the research team via presentations and written materials to participants from the house-builder. Receptivity to PSS production on new housing developments was considered in light of PSS concepts and knowledge transferred.

\section{Phase 2}

Accessibility was achieved by developing definitions of PSS and household consumption which PSS may substitute and/ or complement on new housing developments. These were developed by the research team. Product and use orientated PSS types were reviewed. However, given the potential of result orientated PSS, detailed in section 1, to improve environmental performance these formed the basis of the PSS definition. Further, drawing on the self service hypothesis (Gershuny and Miles, 1983), conventional household consumption which PSS might substitute and/ complement was defined as self service:

Self Service - involving household goods (material artefacts) which are owned and used by householders to produce a socially desirable outcome for their household. Similar to PSS and indeed almost any service, self service involves the application of labour (informal and non-monetised) to a material artefact - a household good.

A focus group was held in which the definitions developed were transferred by the research team via presentations and written materials to participants from the house-builder. Receptivity to PSS production on new housing developments was considered in light of the definitions transferred.

\section{Phase 3}

A menu of four experimental PSS designs was developed by the research team to achieve accessibility. The menu was developed to satisfy household demand for: home improvement; garden maintenance; house cleaning; laundry (clothing and linen) on the house-builder's new housing developments. Process maps of the four experimental PSS were elaborated. Given the challenges of managing waste electrical and electronic equipment (WEEE), the four experimental PSS designs were developed to prevent this. The menu of experimental PSS was subsequently transferred to the house-builder and service providers from its facilities management supplier network. Two focus groups were held for this purpose. First, with participants from the house-builder and second, with participants from the FM service providers. The menu of PSS were transferred by the research 
team via presentations and written material. Receptivity to PSS production on new housing developments was considered in light of the menu of four PSS.

\subsection{Using the analytical framework to analyse receptivity to PSS production on new UK housing developments among participating firms from the UK construction sector}

Receptivity was considered during each phase of the PSS transfer process detailed above. Data were collected for this purpose in the four focus groups and via an additional thirteen interviews held with representatives of participating firms to gain further in depth insights on PSS production. Data were also collected from corporate documentation as necessary, e.g. to obtain details of the house builder's new housing developments. Since little is known about receptivity to PSS production in the UK construction sector, the research was classified as exploratory and qualitative data collected and analysed (Robson, 2002). Data collection was largely separated from technology transfer processes to minimise the affect of the latter on receptivity. For example, within the focus groups this was achieved via a division of labour among the research team: some team members led PSS transfer activity, while others focused on data collection. Data were collected through audio recordings and note taking.

Consistent with the evolutionary theory of technological change underpinning the analytical framework, participants were asked to consider PSS production as a possible response to the demands of their firm's selection environments. Participants were asked to identify 1) aspects of their firm's external selection environment to which PSS production on new housing developments may provide utility as a response, e.g. legislation; 2) aspects of their firm's internal selection environments which PSS production on new housing developments must match, e.g. corporate competence. The analytical framework was used to guide this process, as a heuristic: participants considered aspects of their firm's selection environments such as legislation and corporate competence identified in the analytical framework. While participants were asked to identify additional categories of factors in their selection environments which affect PSS production, none were identified.

Data collected were analysed using the template approach to coding and clustering (Miles and Huberman 1994; Robson, 2002). However, rather than derive initial template codes from literature or a read of the data, as was done to develop the analytical framework, template codes from the analytical framework (e.g. corporate competence) were used to form the basis of a template to facilitate analysis. Thereafter the same approach, detailed in section 2.1, to analysing text segments and generating clusters used to develop the analytical framework was adopted. The resultant template of codes and clusters was subsequently compared with the analytical framework, which includes details of factors found to influence receptivity in the UK manufacturing sector. Similarities and differences between factors affecting receptivity to PSS production in the manufacturing and construction sectors were explicated and are detailed in section 3.

In summary, this paper reports exploratory research which identified and compared rich insights on factors affecting receptivity to PSS production in two sectors. It provides a platform of knowledge for further research which may explain receptivity to PSS production in the form of causal relationships (Robson, 2002). The analytical framework has now been used to guide exploratory research in both the UK manufacturing and construction sectors. However, in the absence of further research to establish causality to complement rich insights provided here, it must still retain the status as a heuristic: a guide for further research on receptivity to PSS production. This paper shows that broad 
categories of factors affecting receptivity to PSS production identified within the analytical framework such as corporate competence may apply in other sectors and guide research accordingly. However, specific factors affecting receptivity to PSS production (e.g. specific corporate competences required for PSS

production), whether they manifest as drivers or barriers may always be context specific and should not be generalised in the absence of further research. While this paper focuses on the receptivity element of the AMR approach, further research might be usefully completed to review the accessibility and mobility of PSS concepts.

\section{Receptivity to Product Service Systems}

A number of factors affecting receptivity to PSS production were identified in the house-builder's and facilities management service providers' selection environments. Rich accounts of these are presented below and compared with those found in UK manufacturers' selection environments to affect receptivity to PSS production in intermediate markets. This section is organised around the template codes of the analytical framework, which are common to both the manufacturing and construction sector study. Since the analytical framework is a heuristic, the template codes are expressed as normative guidelines associated with receptivity to PSS production at the beginning of each sub section.

\subsection{External Selection Environment}

PSS production was thought by participants from the house-builder to provide a response to a range of pressures arising in the firm's external selection environment. For example, PSS production was viewed by participants as an environmental initiative which might help the house-builder attain planning permission for new housing developments. Similarly, given that PSS are services participants from the house-builder stated that PSS production may provide opportunities to differentiate and gain competitive advantage in a mature market for after sales products dominated by goods. External factors found to affect receptivity to PSS production were: knowledge residing in the external environment, the availability of PSS concepts and knowledge in particular, market conditions facing the firm, legislation, in the form of environmental regulations and policies.

\subsubsection{Knowledge residing in the external environment}

Receptivity to PSS production arises when PSS concepts and their knowledge sets are available in the external selection environment of the firm

Although a variety of firms from different sectors have used their products to provide services, few have deliberately developed PSS to improve environmental performance. Instead PSS concepts have largely emerged from academic rather than commercial circles (cf. Wong, 2004). Thus while it is not impossible for firms to produce PSS which improve environmental performance when such knowledge is absent, receptivity to PSS production may be stimulated when PSS concepts and their knowledge sets (e.g. data on potential environmental performance) developed in academic circles are available in firms' external selection environments. In this instance, such knowledge was transferred into the external selection environments of a house-builder and firms from its facilities management supplier networks using the AMR approach detailed in section 2 above.

At the beginning of the AMR process, awareness of PSS concepts and knowledge differed between participants in the manufacturing study and those from the UK construction sector. Participants from manufacturing firms were aware of service offerings in their sector but unaware of PSS concepts and their potential to 
improve environmental performance. Participants from the house-builder were aware of various service offerings such as facilities management services but were not aware of a trend to provide services as part of their core business house-building. However, participants from the house-builder stated that prior to engaging in the project their firm had developed a car sharing scheme with third parties on one of its new housing developments. Although participants from the house-builder did not know whether this scheme had improved environmental performance and thus if it could be deemed a use orientated PSS. Also they were unaware of the range of PSS types and their potential to improve environmental performance and satisfy aspects of household demand other than for mobility. Although service provision was the main focus of the facilities management service providers, participants from these were unaware of PSS concepts and their potential to improve environmental performance and gained knowledge of these via the project.

Limits to the PSS concept's knowledge set was found to inhibit receptivity to PSS production among UK manufacturers, the house-builder and facilities management service providers. Uncertainty associated with the commercial performance of PSS was of particular concern to participants from the housebuilder and its service providers. They stated that greater knowledge of the factors affecting adoption and anticipated adoption rates was needed. Participants from these firms expressed a preference for 'market research' to address these deficiencies: they suggested that the results of such research provide a basis of legitimate claims about potential commercial performance, consumer behaviour and thus a foundation for investment decisions.

\subsubsection{Market conditions facing the firm}

Receptivity to PSS production arises when such projects provide an adequate response to perceived changes in the market conditions facing the firm.

Within the manufacturing study, market conditions facing firms were found to be among the most influential factors affecting receptivity to PSS production in the external selection environments of participating firms. PSS concepts were perceived to offer utility as a response to changes in market conditions; namely, reduction in the number of business opportunities, increasing sensitivity to cost, commoditisation, customer preference for services, a trend to relocate manufacturing activities in so called low cost locations where the factors of production, labour in particular, are relatively inexpensive.

Market conditions were also found to influence receptivity to PSS production in the UK construction sector. However, in contrast to the manufacturing study significant changes in market conditions to which PSS production on new housing developments provide a possible response were not be identified. Participants from the house-builder were not aware of trends to provide services such as PSS in portfolios of after sales products or indeed as part of house-building activity more generally in response to changes in market conditions. They noted that the UK construction sector preferred tried and tested ideas and that the market for after sales products was mature. Thus PSS concepts were classified by participants from the house builder as novel and PSS production thought to provide opportunities for differentiation in after sales markets, to gain additional revenue and competitive advantage. However, while PSS production was deemed by these participants to be commercially interesting and worth exploring, they did not identify significant changes in market conditions facing the house-builder to which PSS production provided a response. 


\section{Customer Preferences for PSS}

In contrast to the manufacturing study, participants from the house-builder did not have a clear view of whether their customers (households) would be willing to adopt PSS. Perceptions varied between participants from different functions of the firm. Participants from the after-sales function stated that ownership of household goods was a key aspiration of households moving onto new housing developments and suggested that this trend is likely to continue. In contrast, participants from the facilities management (FM) division suggested that if reliable PSS were available, households might substitute PSS for conventional consumption methods and even be tempted to relinquish ownership of household goods. However, all participants from the house-builder agreed that those moving onto new housing developments seemed to be generally more aware of environmental issues than before and that this may be expressed in their consumption choices. Those from the FM division suggested that this disposition might contribute to a willingness to adopt PSS.

Participants from the house-builder stated that use orientated PSS such as the leasing of household appliances (e.g. ovens, fridge freezers, washing machines) would be of little interest to households. Participants from all functions of the house-builder suggested that the relative price of use orientated PSS compared with product ownership is likely to present a significant barrier to adoption. Participants suggested that households would pay more to lease household goods than to purchase them outright. However, they also suggested that in terms of status, leasing goods might fulfil the same need as owning, as visitors to households would not be able to differentiate household goods owned from those leased.

\section{Production on new housing developments}

One way to minimise the environmental impacts of PSS is to provide on site facilities for PSS production on new housing developments and thereby reduce transport distances in PSS delivery. For example, on site service centres could house laundry facilities to support result orientated PSS providing clean clothes and linen to households and/ or use orientated PSS such as garden tool sharing schemes. However, changes in market conditions were not identified to stimulate development of such facilities to support PSS production. Participants from the house builder found it difficult to conceive of giving up a house plot for a PSS facility. Participants from the house builder stated that given the value of land and property in the UK, there was little incentive for house-builders to set aside land for facilities to enable different forms of equipment sharing (e.g. for gardening, DIY) and service provision generally. Participants stated that the risk reward ratio associated with PSS production on new housing developments would need to be explored further before housing plots could be given serious consideration. Participants stated that such service centres may be stimulated by spatial planning requirements to provide community facilities and that sharing schemes might be developed through among other things, social marketing.

Participants from the facilities management service providers stated that PSS production might be usefully targeted at: housing developments which include a significant proportion of higher income households as these may be more likely to adopt PSS than lower incomes households; high density housing developments as these may offer sufficient geographical density of demand to minimise costs associated with PSS delivery, e.g. travel between sites. However, participants from the FM service providers did not identify changes in market conditions, for example, a decline in business opportunities or value in their markets to which PSS production as part of the house-builder's portfolio of after sales products provide a response. Rather they stated that there was sufficient demand for their 
services in the intermediate markets they currently operate in and that moving into PSS production on new housing developments was unattractive.

\subsubsection{Legislation \\ Receptivity to PSS production arises when such projects provide an adequate response to environmental regulations and policies.}

Within the manufacturing study, PSS production was thought to provide utility as a response to a number of environmental regulations, including most notably the Waste Electrical and Electronic Equipment Directive (WEEE Directive). However, since the manufacturing study was completed, the impact of the WEEE Directive on production has been the subject of considerable debate. Some studies suggest that the WEEE Directive has stimulated environmental innovation/ eco-design, while others suggest that the Directive has changed waste management practice (Hagelskjaer et al., 2010).

Participants from the house-builder stated that they initiated projects which helped their firm attain planning permissions. The efficient attainment of planning permissions is a requisite core competence of UK speculative housebuilders (Adams, 2004). As noted above, a car sharing scheme had been introduced on one of the house-builder's developments. Participants stated that this was introduced to provide mobility to residents since the development did not include infrastructure for private cars and to help attain planning permission for the development. In general, both public and high level political support and interest appeared to be key drivers for this scheme. Development of use orientated PSS such as household equipment sharing were also discussed. Participants from the house-builder expressed concern regarding health and safety regulations and associated liabilities with on site facilities to store shared equipment and therefore did not see it as an attractive option. Thus while planning regulations may drive PSS production on new housing developments, other regulations might inhibit this.

Participants from the facilities management service providers recognised the importance of environmental issues. However, they suggested that environmental concerns would not provide the basis of a persuasive argument for their firms to deliver PSS on new housing developments. While their firms complied with all relevant regulations, including environmental regulations, participants could not identify a regulation or policy which would stimulate them to supply PSS in this context.

\subsection{Internal Selection Environment}

For a firm to be receptive to PSS production, such projects must fit within its internal selection environment. Aspects of firms' internal selection environments which influence receptivity to PSS production include strategic orientation, product portfolio, organisational structure and corporate competence.

\subsubsection{Strategic Orientation}

Receptivity to PSS production arises when such projects are consistent with the firm's strategic orientation.

Receptivity is thought to arise when PSS production is consistent with a firm's overarching approach to tackling changes in its external selection environment. This is defined here as a firm's strategic orientation. Within the manufacturing study receptivity arose in firms which had already developed and/ or acquired (e.g. via strategic alliance) competences necessary to supply services in response to pressures emanating from their external selection environments. 
Manufacturers stated that PSS concepts provided utility to their strategic efforts to seek greater differentiation, greater economies of scope, to attain competitive advantage from environmental regulation in particular.

Participants from the house-builder stated that the firm sought to gain competitive advantage through differentiation in after sales products. Since portfolios of after sales products generally comprise household goods (e.g. washing machines, carpets), participants suggested that PSS concepts offer opportunities for differentiation in a mature market for after sales products. Thus PSS concepts were deemed by participants from the house-builder to provide a possible response to planning regulations as well as opportunities for differentiation and competitive advantage. However, participants from the facilities management division of the house builder stated that supplying PSS concepts to new housing developments might challenge the firm since its strategy focused on the provision of services to a small number of large commercial clients. In contrast, PSS production on its new housing developments represented a significant departure from this strategy as it would require the house builder to supply services to a large number of small domestic clients. Thus while the house-builder had many business systems in place to support PSS delivery, participants from the house-builder stated that PSS production on new housing developments would be likely to require new ones to be built or existing ones to be developed and adapted. They stated that a cost would be associated with these activities which may be difficult to justify in light of uncertain benefits from PSS production in this context.

\subsubsection{Customer Relations}

Within the manufacturing study, firms viewed PSS production as providing opportunities to learn about the performance of their goods during the use phase and to gain knowledge which may be useful in new product development. For the house-builder, the role of PSS production in the attainment of corporate strategy with regard to customer relations was ambiguous. On the one hand, participants from the house builder stated that within the sector, there is a desire to close sales with households, i.e. complete one off transactions. These participants stated that in general, UK house-builders maintain contact with households while they address defects (often referred to as snags) in new housing during a warrantee period, e.g. approximately two years. Participants from the house builder observed that the idea of prolonging customer contact through PSS delivery on new housing developments did not match this strategy. However, on the other hand, these participants stated that the idea of building long term relationships with customers, customer trust and loyalty through PSS production was a good one. They suggested that relations built through PSS production might provide opportunities for further house sales, to gain knowledge of and satisfy new lifestyle preferences. However, they also stated that quality and reliability of PSS would need to be excellent, if not they could lose valued customers.

Similar to facilities management division of the house-builder, participants from the FM service providers expressed a preference to provide services to a small number of large clients. They observed that supplying PSS to new housing developments represented a significant departure from this strategy. Participants from the service providers also stated that levels of profit associated with PSS delivery would largely determine receptivity to PSS production in facilities management supplier networks. They expressed a preference for tried and tested ideas with known levels of profitability. As noted above, the PSS concept's knowledge set was deemed by participants from the house-builder to be lacking in this respect. Similar to the house-builder, market research was seen by participants from the facilities management service providers as a source of 
legitimate knowledge for investment decisions. However, these participants also suggested that if long term service agreements could be agreed on a voluntary basis with households moving onto new housing developments then investment necessary for PSS production may be possible.

\subsubsection{Product Portfolio}

Receptivity to PSS production arises when firms have product portfolios which include services and goods with certain characteristics.

The manufacturing study showed that receptivity arose in firms with product portfolios which included services, e.g. for maintenance and repair. Indeed, the quasi evolutionary nature of PSS concepts suggests that receptivity to PSS production arises when services are already present in a firm's product portfolio. Participants from the house-builder and corporate documents showed that there were a range of services in the house-builder's product portfolio. Consistent with the UK house building sector, the firm provided warrantee services (similar to product orientated PSS) via the National House Building Council which cover the design and construction of houses. As noted above, the house-builder had also helped establish a car sharing scheme on one of its recent developments. Also, through its facilities management division, participants from the house-builder stated that it provided a range of services to commercial clients in business to business markets. However, these participants noted that the house-builder's product portfolio was dominated by material artefacts: houses, i.e. high value goods; while its portfolio of after sales products was dominated by household goods including carpets, curtains and household appliances and did not include services. Participants from the house-builder stated that PSS may provide an opportunity to develop a differentiated after sales offering in a mature market.

\subsubsection{Organisational Structure}

Receptivity to PSS production arises when a structure is present that can facilitate the inward transfer of PSS concepts .

While the structures of firms which took part in the manufacturing study varied, there was little difference between the characteristics of firm structures which influenced receptivity to PSS concepts. Receptivity did not arise in firms which only had structures in place to support efficient manufacturing. While in a number of instances structures to supply services were present, they had been stripped away as a result of the trend to focus on core manufacturing competences. However, receptivity did arise in manufacturers where structures remained or had been built to enable service supply, e.g. to facilitate an ongoing dynamic relationship with customers as opposed to one off discrete transactions. Corporate documents showed that the house-builder's structure comprised one division focused on property development (land acquisition, marketing and sales) and another focused on construction and facilities management. Participants from the house-builder stated that structures necessary to manage complex projects were present, while those necessary to enable service management and delivery were concentrated in the facilities management division.

Within the firms which took part in the manufacturing study and the housebuilder, the presence of a 'PSS champion' in the firms' structures was found to influence receptivity to PSS production, with the role and position of the individual within these being important. Within the house-builder, inward transfer of the PSS concept was championed by its representative on the project management team. Prior to this project, this actor had been involved in a publicly funded research project concerned with the development of PSS concepts in commercial contexts. He was located within a technology consultancy embedded in the construction and facilities management division of the firm, had a good working 
knowledge of all aspects of the house-builder and contacts necessary to draw teams together for PSS production. Observations showed that the impact of this PSS 'champion' on achieving integration across various business functions (e.g. facilities management, after sales, customer services), in translating codified knowledge of PSS and context in the technology transfer process had a significant impact on receptivity.

\subsubsection{Corporate Competence \\ Receptivity to PSS production arises when competences necessary for inward transfer of PSS concepts are present.}

As noted above in section 3.1.1, PSS concepts have by and large been developed in firms' external selection environments, within public funded research projects involving universities and associated research focused institutions. Thus in both the manufacturing study and house-builder, receptivity to PSS production is thought to arise when there exists a corporate competence to successfully inward transfer PSS concepts. The 4A model (Trott, 2005) suggests that successful inward transfer of PSS is dependent on the presence of capabilities to become aware of PSS concepts, to associate them with internal attributes of the firm and value them, to assimilate them within firm structures and apply them.

Inward transfer of the PSS concept

Awareness - A number of firms which took part in the manufacturing study held memberships of green business networks and learnt of environmental technologies through these. Participants from the house-builder stated and corporate documents showed that within the house-builder, a dedicated in house consultancy (in which the PSS champion worked) scanned the firm's external environment for sustainable construction technologies and environmental assessment methods. This internal grouping worked with UK government departments and agencies (e.g. Building Research Establishment, Environment Agency) and may to some extent, play a role in shaping the house-builder's external environment. Further, participants from the FM division stated that scanning U.S. markets had identified concierge services which aim to meet certain lifestyle preferences. Participants from the house builder stated that these service offerings had been discussed in the firm before it engaged in this research project. They also stated that they had recently attended a conference at which cleaner product concepts similar to PSS had been discussed. Among other things, these findings suggest that the house-builder demonstrated corporate capability to scan markets and networks to identify environmental technologies such as PSS and various service offerings.

Association - within the manufacturing study, firms which had developed requisite competence for service delivery were receptive to PSS partly because they associated services with certain pressures emanating from their external selection environments. Similarly, participants from the house-builder stated that it had developed competence to supply services. Participants were able to identify a range of factors in the firm's external selection environment to which PSS production could provide a possible response, e.g. to differentiate in a mature market for after sales products, to planning regulations.

Assimilation - as noted earlier, within both the manufacturing study and housebuilder, project champions played prominent roles in assimilating PSS within organisational structures. For example, within the house-builder, the PSS champion identified participants from a number of functions of the firm and allocated roles for them in PSS transfer and production. 


\section{Corporate Competence to apply PSS}

Finally, for successful inward transfer firms must have the organisational capabilities to apply the PSS concept, i.e. to produce PSS. Within the manufacturing study, firms receptive to PSS production had developed requisite capabilities to supply services in response to external pressures. Participants from the house-builder suggested that uncertain PSS performance meant that future costs and revenues and consequently the commercial viability of PSS production was difficult to identify. They stated that therefore, construction of significant corporate competence for PSS production on new housing developments would not be feasible; PSS would need to be developed which matched existing corporate competence available in the house-builder and its facilities management supplier network.

Participants from the house-builder stated that the competences of the housebuilder and its supplier network were aligned with product orientated PSS concepts such as household maintenance and repair services, and result orientated PSS concepts such as house cleaning and laundry. They stated that both facilities management and customer service functions of the firm had requisite corporate competence to manage PSS delivery: capabilities to agree service levels; manage supplier and customer contacts; respond to customer calls and source best value service providers for PSS delivery on new housing developments. Participants from the house-builder with responsibility for after sales stated that they were familiar with customer product and lifestyle preferences and were proficient in managing transactions with households. However, while these participants were confident that the house-builder had requisite competence to manage PSS production on new housing developments, they would contract service providers for on site delivery. Participants from the house-builder suggested that the market for household services was fragmented and that they would not want to deal with a plethora of small service providers. National and regional service providers from the house-builder's facilities management supplier network would be sought to minimise transaction costs and achieve requisite economies of scale in PSS delivery. Within the manufacturing study, firms had built competences necessary to provide services and/ or accessed these via supplier networks or strategic alliance.

Participants from the facilities management service providers stated that they did not have the competence to supply PSS to new housing developments and investment would be required to do so. As detailed above, FM service providers typically provide services to a small number of large clients. In contrast, PSS production on new housing developments requires different competences for among other things, customer relationship management- to supply PSS to a large number of small customers. Participants from these firms stated that given the lack of knowledge about the commercial viability of PSS production on new housing developments, their firms had little appetite to acquire or build corporate competence necessary to supply PSS on new housing developments.

\section{Conclusions}

A waste prevention assessment completed in the project showed that the four experimental PSS designs developed in the project hold potential to prevent WEEE arising from households on new housing developments (Reference removed to ensure anonymity). However, a number of challenges associated with receptivity to PSS production in this context are identified in this paper. Similar to the findings of the manufacturing study, a number of factors were found in the house-builder's external selection environment to which PSS production could provide a possible response to, including: to develop a differentiated after sales product; to achieve competitive advantage in a mature market for after sales 
products; and to assist in the attainment of planning permissions. However, while manufacturers detected a clear trend among their customers to consume services, the house-builder was unsure of the potential of PSS to satisfy household demand. On the one hand, it was thought that households might continue to consume household goods in the foreseeable future, while on the other that the availability of reliable PSS and environmental concerns might stimulate PSS consumption. Also, while manufacturers liked the idea of entering into long term relationships with their customers, the house-builder suggested that PSS delivery was challenged by the sector wide strategy of completing sales. However, both manufacturers and the house-builder thought that long term relationships may provide information to support new product development. The work of a 'PSS champion' in integrating business functions in PSS development and delivery was highlighted in both the house-builder and manufacturing study.

Overall, drivers for PSS production found in the external selection environment of the house-builder do not appear to be as strong as those identified in the manufacturing study. While participants from the house-builder were aware of new service offerings such as car sharing schemes and concierge services on UK and US markets respectively, a strong market signal could not be detected for PSS delivery to satisfy aspects of household demand. Also, while planning policy and regulation were identified as potential drivers for PSS production on new housing developments, a specific aspect of these which would drive PSS production in particular, was not identified. Geographic effects were found to influence receptivity to supply PSS within the manufacturing study, house-builder and service providers. Manufacturers were receptive to PSS production in response to relocation of manufacturing activities. As a result of high UK land values, the house-builder could not conceive of giving up a plot on new housing developments for PSS delivery.

While PSS may provide opportunities for house-builders to develop differentiated after sales products, this research suggests that it may difficult for such firms to acquire requisite competence for PSS delivery on new housing developments via facilities management supplier networks. Corporate capability to manage delivery of PSS was available in the house-builder. Indeed, the capability to integrate many activities across a vast network of actors is an important source of competitive advantage in house-builders (Adams, 2004). However, the facilities management service providers showed little interest in PSS delivery. Participants from these stated that there was sufficient work in their core markets and that therefore, a move into PSS delivery to households would be difficult to justify. Investment in requisite business systems and processes to provide PSS to a large number of small customers represented a significant departure from their corporate strategy and investment was deemed particularly challenging given limits to the PSS concept's knowledge set.

At a higher level of abstraction, conventions of good business practice in certain sectors and in general may facilitate the development and delivery of PSS concepts, while others may constrain this activity. For example, the need to develop differentiated products in a mature market for after sales products and the existence of competence to manage complex projects in house-builders may facilitate the development of PSS concepts. On the other hand, a preference to close sales, undertake activities which closely match core competences and provide services to a small number of large clients may be seen to constrain PSS development. However, this paper draws on exploratory research and further research is required to explicate the findings presented and explore PSS futures more fully. For example, business discourses emphasising service dominant logic (Vargo and Lusch, 2004) and integrated solutions (Brady et al., 2005) may form the basis of conventions of good business practice in the future. 
PSS concepts build on ongoing socio-technical dynamics and are therefore quasi evolutionary. This suggests that PSS have a greater chance of success in contexts where services have been developed, produced and consumed. Within the manufacturing study, firms which had already developed services were receptive to producing PSS for the markets they served. While a service orientation can be found in the construction sector and associated facilities management firms, PSS production on new housing developments would not build on ongoing trends to provide services in intermediate markets. Importantly, this highlights the idea that there are different service competences and that it cannot be assumed that firms with service competences will simply be receptive to PSS production. Thus further research in which receptivity to produce PSS among actors which are already engaged in household service provision is required. For example the potential of small and medium sized enterprises (SME) service providers in PSS production has been highlighted (Halme et al, 2008). In such instances, externally accredited environmental management procedures and eco-labels tailored to PSS delivery may be needed to help smaller organisations identify and manage environmental aspects of services, i.e. to produce PSS.

\section{Acknowledgements}

Need to be inserted if paper is accepted for publication. Removed to ensure author anonymity in review process. 


\section{References}

Adams D., 2004. The changing regulatory environment for speculative housebuilding and the construction of core competences for brownfield development. Environment and Planning A 36, 601-624.

Baines TS, Lightffot HW, Evans S, Neeley A, Greenough R, Peppard J, Roy R, heha $E$, Brangaza A, Tiwari A, Alcock JR, Angus J, Bastl M, Cousens A, Irving $P$, Johnson M, Kingston J, Lockett $\mathrm{H}$, Martinez V, Michele P, Tranfield D, Walton I, Wilson H., 2007. State of the art in product service systems. Journal of Engineering Manufacture 221, 1543-1552.

Bartolomeo M, dal Maso D, de Jong $\mathrm{P}$, Eder $\mathrm{P}$, Groenwegen $\mathrm{P}$, Hopkinson $\mathrm{P}$, James $P$, Nijhuis L, Orringe M, Scholl G, Zaring O., 2003. Eco-efficient producer services - what are they, how do they benefit customers and the environment and how likely are they to develop and be extensively utilised? Journal of Cleaner Production, 11: 829-837.

Behrendt S, Jasch C, Kortman J, Hrauda G, Firzner R, Velte D., 2003. Eco-service Development: Reinventing Supply and Demand in the European Union. Greenleaf Publishing, Sheffield.

Brady T, Davies A, Gann D., 2005. Can integrated solution business models work in construction? Building Research and Information 33, 571-579.

Brezet JC, Bijma AS, Ehrenfeld J, Silvester S., 2001. The design of eco-efficient services. Delft:report by TU Delft for the Dutch Ministry of the Environment.

Bryson JR, Daniels PW, Warf B., 2003. Service worlds: people, organisations, technologies. Routledge, London.

Ceschin F, Vezzoli C., 2010. The role of public policy in stimulating radical environmental impact reduction in the automotive sector: the need for focus on product service system innovation. International Journal of Automotive Technology and Management 10, 321-339.

Cook M, Bhamra T, Lemon M., 2006. The transfer and application of Product Service Systems: from academia to UK manufacturing firms. Journal of Cleaner Production 14, 1455-1465.

Elzen B, Geels FW, Green, K., 2004. System innovation and transition to sustainability: theory, evidence and policy. Edward Elgar, Cheltenham.

Gershuny J, Miles I., 1983. The new service economy: the transformation of employment in industrial societies. Pinter, London.

Goedkoop MJ, Halen C, Riele H, Rommens P, 1999. Product Service Systems, Ecological and Economic Basics,. Netherlands: PricewaterhouseCoopers, Storrm, Pré Consultants for Ministry of Economic Affairs.

Hagelskjaer Lauridsen E, Jorgensen U., 2010. Sustainable transition of electronic products through waste policy. Research Policy 39, 486-494.

Halme M, Jasch C, Scharp M., 2004. Sustainable homeservices? Toward household services that enhance ecological, social and economic sustainability. Ecological Economics 51, 125-138. 
Halme M, Anttonen M, Hrauda G, Kortman J., 2006. Sustainability evaluation of European household services. Journal of Cleaner Production 14, 1529-1540.

Halme M, Hrauda,G, Jasch C, Kortman J, Jonuschat H, Scharp M, Velte D, Trindade P., 2008. Sustainable consumer services: Business solutions for household markets. Earthscan, London.

Hawken P, Lovins A, Lovins H., 1999. Natural Capitalism. Earthscan, London.

Hockerts K., 1999. Innovation of eco-efficient service: increasing the efficiency of products and services. In: Charter, m., Polonsky MJ, editors, Greener Marketing: a global perspective on greener marketing practice. Greenleaf Publishing, Sheffield.

Howells, J., 2002. Innovation, consumption and services: encapsulation and the combinational role of services, paper presented at the $12^{\text {th }}$ international RESER conference, 26-27 September, 2002, Manchester.

Manzini E, Vezzoli C. A strategic design approach to develop sustainable product service systems: examples taken from the 'environmentally friendly innovation' Italian prize. Journal of Cleaner Production 11, 851-857.

Meijkamp R., 2000. Changing consumer behaviour through 'eco-efficient services: an empirical study on car sharing in the Netherlands. Delft University of Technology, The Netherlands.

Miles and Huberman (1994) Qualitative Data Analysis, Sage, California, US.

Mont, O., 2004. Institutionalisation of sustainable consumption patterns based on shared use. Ecological Economics 50, 135-153.

Mont, O. and Lindhqvist, T., 2003. The Role of Public Policy in Advancement of Product Service Systems. Journal of Cleaner Production 11, 905-914

Mont O, Tukker A., 2006. Product-service systems: reviewing achievements and refining the research agenda. Journal of Cleaner Production 14, 1451-1454.

Mont O, Emtairah T., 2008. Systemic changes and sustainable consumption and production. In Tukkker a, Charter M, Vezzoli c, editors. System innovation for sustainability: perspectives on radical changes to sustainable production and consumption v1. Greenleaf Publishing, Sheffield.

Morreli N., 2006. Developing new product service systems (PSS): methodologies and operational tools. Journal of Cleaner Production 14, 1495-1501.

Nelson, R. and Winter, S. An Evolutionary theory of Economic Change, Belknap Press, Cambridge Mass.

Robson, C (2002) Real World Research, Blackwell Publishing, Oxford, UK

Roy R., 2000. Sustainable Product-Service Systems. Futures 32, 289-299.

Seaton, R, Cordey-Hayes, M., 1993 The development and application of interactive models of industrial technology transfer. Technovation 13, 45-43. 
Seaton R, Jeffrey P, Stephenson T, Pasons S., 1998. From marketing to receptivity: structuring community involvement in integrated catchment management. In proceedings of WATERTECH. Brisbane, Australia.

Sorrell S., 2007. The economics of energy service contracts. Energy Policy 35, 507-521.

Stahel W. 2006. The performance economy. Palgrave Macmillan, New York.

Steinberger J, van Niel J, Bourg D., 2009. Profiting from negawatts: reducing absolute consumption and emissions through a performance-based energy economy. Energy Policy 37, 361-370.

Tischner U, Verkuiji M, Tukker A., 2002. Product service systems: best practice document: SusProNet. Professional Engineering Publishing Limited.

Trott P., 2005. Innovation management and new product development. Prentice Hall, Harlow.

Tukker A, Tischner U., 2006. New Business for Old Europe: Product-service development, competitiveness and sustainability. Greenleaf Publishing, Sheffield.

Tukker A, Tischner U., 2006. Product-services as a research field: part, present and future. Reflections from a decade of research. A note from the field. Journal of Cleaner Production 14, 1552-1556.

Weizsacker E, Lovins A, Lovins H., 1997. Factor four. Earthscan, London.

van den Hoed, R., 1997. Shift from products to services: an example of washing services. Proceedings 'Towards Sustainable Product Design', $2^{\text {nd }}$ international Conference, London.

Vargo S, Lusch R., 2004. Evolving to a new dominant logic for marketing. Journal of Marketing 68, 1-17.

Williams A., 2007. Product service systems in the automobile industry: contribution to system innovation? Journal of Cleaner Production 15, 1093-1103.

Williams J., 2010. The deployment of decentralised energy systems as part of the housing growth programme in the UK. Energy Policy 38, 7604-7613.

Wong M., 2004. Implementation of innovative Product Service Systems in the customer goods industry. Unpublished Doctoral Dissertation, University of Cambridge, Cambridge, UK.

Zaring O, Bartolomeo M, Eder $\mathrm{P}$, Hopkinson $\mathrm{P}$, Groenwegen $\mathrm{P}$, James $\mathrm{P}$, de Jong P, Nijhuis L, Scholl G, Slob A, Orringe M., 2001. Creating eco-efficient producer services. Gothenburg Research Institute, Sweden. 
Table 1 Factors identified that affect receptivity to PSS production among UK manufacturing firms (Cook et al. 2006)

\section{External Selection Environment \\ Knowledge residing in the external environment}

The PSS concept and its requisite knowledge set must be available in the external selection environment of firms; these must be in an accessible form; and a mobility channel must be available to enable the transfer of these from academic circles to industry.

Market conditions facing the firm

The PSS concept must provide a response to perceived changes in the market conditions facing a firm. These include: the need to add value and to attain greater economies of scope.

\section{Legislation}

The PSS concept must provide a response to environmental legislation, and in particular, legislation which has been developed to engender extended producer responsibility such as the WEEE Directive.

\section{Internal Selection Environment}

\section{Corporate Competence}

Competencies for technology/ knowledge transfer must exist; particularly those that are required to acquire the PSS concept and its knowledge set from a firm's external selection environment and to assimilate these into organisational structure;

Competencies to apply the PSS concept: those required to use the service type of transaction

Strategic Orientation

The PSS concept must be consistent with the firm's strategic orientation;

Firms must be seeking greater differentiation;

Firms must be seeking greater economies of scope;

Firms must be seeking to attain competitive advantage from compliance with environmental legislation;

There must be a corporate commitment to improving environmental performance.

Organisational Structure

A structure that can facilitate the acquisition, assimilation and application of the PSS concept.

Product Portfolio

High value products from which sufficient revenue can be secured to finance the acquisition of any additional competencies needed for service delivery;

Service orientated products in product portfolio;

Tangible products could be easily disassembled and upgraded to account for chanaes in technoloav and fashion.. 
Fig. 1. The Transfer of Product Service Systems from the academic sector using the AMR approach (after Cook et al. 2006)

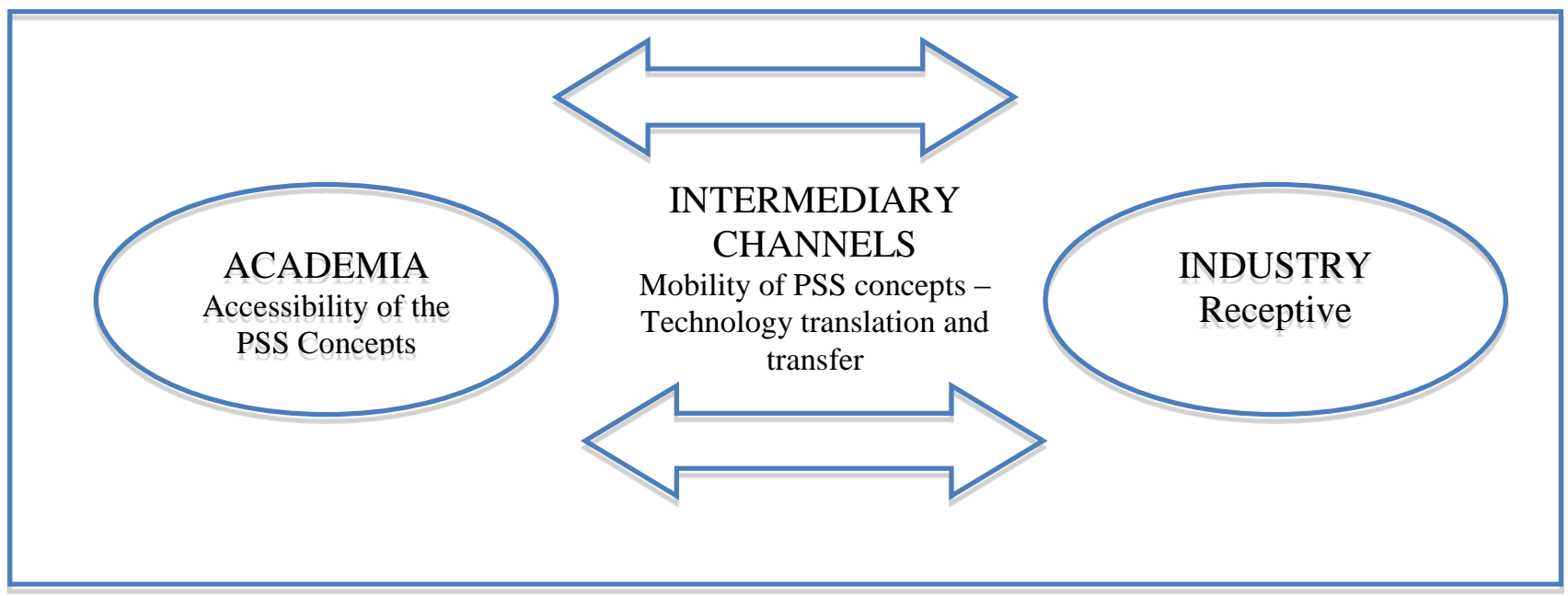

